\title{
Methylparaben concentration in commercial Brazilian local anesthetics solutions
}

\author{
Gustavo Henrique Rodriguez da SILVA¹, Carla Beatriz Grespan BOTTOLI², Francisco Carlos GROPPO ${ }^{3}$, Maria Cristina \\ VOLPATO $^{3}$, José RANALI ${ }^{3}$, Juliana Cama RAMACCIATO ${ }^{4}$, Rogério Heládio Lopes MOTTA ${ }^{4}$ \\ 1- DDS, Department of Analytical Chemistry, Institute of Chemistry, University of Campinas, Campinas, SP, Brazil. \\ 2- Chem, PhD, Department of Analytical Chemistry, Institute of Chemistry, University of Campinas, Campinas, SP, Brazil. \\ 3- DDS, PhD, Chairman, Department of Pharmacology, Anesthesiology and Therapeutics, Piracicaba Dental School, University of Campinas. Piracicaba, \\ $\mathrm{SP}$, Brazil. \\ 4- DDS, PhD, Department of Pharmacology, Anesthesiology and Therapeutics, São Leopoldo Mandic Dental School, Campinas, SP, Brazil.
}

Corresponding address: Prof. Dr. Rogério Heládio Lopes Motta - Faculdade de Odontologia São Leopoldo Mandic - Área de Farmacologia, Anestesiologia e Terapêutica - Rua Dr. José Rocha Junqueira, 13 - Ponte Preta - Campinas - SP - Brasil -

13045-755 - E-mail: rogeriomotta@yahoo.com

Received: October 16, 2010 - Accepted: October 8, 2011

\section{ABSTRACT}

\begin{abstract}
$\mathrm{O}$ bjective: To detect the presence and concentration of methylparaben in cartridges of commercial Brazilian local anesthetics. Material and methods: Twelve commercial brands (4 in glass and 8 in plastic cartridges) of local anesthetic solutions for use in dentistry were purchased from the Brazilian market and analyzed. Different lots of the commercial brands were obtained in different Brazilian cities (Piracicaba, Campinas and São Paulo). Separation was performed using high performance liquid chromatography (HPLC) with UVVis detector. The mobile phase used was acetonitrile:water $(75: 25-\mathrm{v} / \mathrm{v}), \mathrm{pH} 4.5$, adjusted with acetic acid at a flow rate of $1.0 \mathrm{ml} \cdot \mathrm{min}^{-1}$. Results: When detected in the solutions, the methylparaben concentration ranged from $0.01 \%(\mathrm{~m} / \mathrm{v})$ to $0.16 \%(\mathrm{~m} / \mathrm{v})$. One glass and all plastic cartridges presented methylparaben. Conclusion: 1 . Methylparaben concentration varied among solutions from different manufacturers, and it was not indicated in the drug package inserts; 2 . Since the presence of methylparaben in dental anesthetics is not regulated by the Brazilian National Health Surveillance Agency (ANVISA) and this substance could cause allergic reactions, it is important to alert dentists about its possible presence.
\end{abstract}

Key words: Hypersensitivity. Allergy. Local anesthetics.

\section{INTRODUCTION}

Local anesthesia continues to be the most used pain control method in dentistry. The knowledge of pharmacology and toxicity properties provides safety and efficacy for the clinical use of anesthetic agents $^{16}$. In Brazil around 250 million anesthetic cartridges are used per year. The low incidence of adverse reactions as related in the literature reflects the great clinical safety of these formulations when correctly used ${ }^{17}$.

In 1904, Einhorn synthesized a new ester anesthetic, procaine, which would replace cocaine and avoid the risk of drug addiction ${ }^{3}$. However, the esters showed a high incidence of allergic reactions caused by their metabolite, the para-aminobenzoic acid (PABA), which results from esters' hydrolysis in plasma ${ }^{6}$. A new chemical group of anesthetics - the amides - appeared with the discovery of lidocaine in the 1940s, improving the safety of pain control in dentistry ${ }^{14}$.

The anesthetics of the amide group successfully replaced the ester anesthetics, which were gradually discarded due to their allergenic potential. In Brazil, ester anesthetics (benzocaine) are used only for topical anesthesia in dentistry. All the local anesthetic solutions, which are available in the injectable form today, belong to the amide group and rarely cause allergic reactions. Cases of allergy have been related due to the preservatives or antioxidants added to the solutions ${ }^{13}$.

The dental anesthetic solutions usually contain an anesthetic (chloride salt) either associated with vasoconstrictors or not, dissolved in a vehicle (sterile water). Antioxidants, mainly sodium or potassium bisulphite, are added to solutions 
containing sympathomimetic vasoconstrictors ${ }^{9}$. These antioxidants are used to assure a reasonable concentration of sympathomimetic amines in the anesthetic solutions. Sodium bisulphite, for example, is used in concentrations from $0.05 \%$ to $0.1 \%{ }^{14}$. These antioxidants act as "suicide components" and delay the vasoconstrictors' oxidation. The sulphites react more quickly with oxygen and other catalysts, protecting the vasoconstrictors ${ }^{8}$. However, the antioxidants can cause allergic reactions, which have been related in the literature?

Another component added to many Brazilian anesthetic solutions is methylparaben, which is also used in cosmetics and food products. The main function of this substance is to act as a bacteriostatic agent and to maintain the sterility of the anesthetic solution ${ }^{13}$.

Similarly to ester anesthetics, methylparaben also produces PABA as a metabolite, which is a highly allergenic substance related to various cases of hypersensitivity ${ }^{4}$. Due to this characteristic, the use of methylparaben in dental cartridges was prohibited in the United States by the regulatory agency - Food and Drug Administration (FDA) - in the mid-1980s ${ }^{9}$. In Brazil, the regulatory agency the Brazilian National Health Surveillance Agency (ANVISA) - has not yet adopted a standardization considering the presence of bacteriostatic agents in dental local anesthetic solutions.

\begin{tabular}{|c|c|c|c|c|c|c|c|}
\hline Sample & $\begin{array}{c}\text { Commercial } \\
\text { Brand }\end{array}$ & $\begin{array}{l}\text { Anesthetic } \\
\text { Composition }\end{array}$ & $\begin{array}{l}\text { Cartridge } \\
\text { Material }\end{array}$ & $\begin{array}{l}\text { Percentage of } \\
\text { methylparaben }\end{array}$ & CV (\%) & $\begin{array}{c}\text { Described } \\
\text { in drug } \\
\text { package } \\
\text { insert? }\end{array}$ & $\begin{array}{l}\text { Concentration } \\
\text { informed? }\end{array}$ \\
\hline 1 & $\begin{array}{c}\text { Lidostesina } \\
100^{\circledR}\end{array}$ & $\begin{array}{l}2 \% \text { lidocaine } \\
\text { 1:100,000 } \\
\text { epinephrine }\end{array}$ & Plastic & 0.01 & 0.77 & Yes & No \\
\hline 2 & $\begin{array}{c}\text { Lidostesina } \\
50^{\circledR}\end{array}$ & $\begin{array}{c}2 \% \text { lidocaine } \\
1: 50,000 \\
\text { epinephrine }\end{array}$ & Plastic & 0.01 & 0.66 & Yes & No \\
\hline 3 & $\begin{array}{l}\text { Lidostesin } \\
\quad 3 \%^{\circledR}\end{array}$ & $\begin{array}{c}3 \% \text { lidocaine } \\
\text { 1:50,000 } \\
\text { norepinephrine }\end{array}$ & Plastic & 0.01 & 4.36 & Yes & No \\
\hline 4 & $\begin{array}{c}\text { Mepivalem } \\
3 \%{ }^{\circledR}\end{array}$ & $3 \%$ mepivacaine & Plastic & 0.01 & 3.96 & Yes & No \\
\hline 5 & Citanest $^{\circledR}$ & $\begin{array}{c}3 \% \text { prilocaine } \\
0.03 \text { Ul felypressin }\end{array}$ & Plastic & 0.01 & 3.79 & Yes & No \\
\hline 6 & Novocol $^{\circledR}$ & $\begin{array}{c}2 \% \text { lidocaine } \\
1: 2,500 \\
\text { phenylephrine }\end{array}$ & Plastic & 0.11 & 1.45 & Yes & No \\
\hline 7 & Cirucaina $^{\circledR}$ & $\begin{array}{c}\text { 0.5\% bupivacaine } \\
1: 100,000 \\
\text { epinephrine }\end{array}$ & Plastic & 0.01 & 0.44 & Yes & Yes \\
\hline 8 & Alphacaine $^{\circledR}$ & $\begin{array}{l}2 \% \text { lidocaine } \\
\text { 1:100,000 } \\
\text { epinephrine }\end{array}$ & Glass & $<\mathrm{LQ}$ & $(-)$ & No & No \\
\hline 9 & Articaine $^{\circledR}$ & $\begin{array}{c}4 \% \text { articaine } \\
1: 100,000 \\
\text { epinephrine }\end{array}$ & Glass & $<\mathrm{LQ}$ & $(-)$ & No & No \\
\hline 10 & Prilonest $^{\circledR}$ & $\begin{array}{c}3 \% \text { prilocaine } \\
0.03 \text { UI felypressin }\end{array}$ & Glass & 0.16 & 2.06 & Yes & No \\
\hline 11 & $\begin{array}{c}\text { Scandicaine } \\
2 \%{ }^{\circledR}\end{array}$ & $\begin{array}{c}2 \% \text { mepivacaine } \\
1: 100,000 \\
\text { norepinephrine }\end{array}$ & Glass & $<L Q$ & $(-)$ & No & No \\
\hline 12 & Citocaina $^{\circledR}$ & $\begin{array}{c}3 \% \text { prilocaine } \\
0.03 \text { UI felypressin }\end{array}$ & Plastic & 0.07 & 7.88 & Yes & No \\
\hline
\end{tabular}

Figure 1- Concentration of methylparaben in different cartridges available on the Brazilian market 
The aim of this study was to analyze the presence and the concentration of the methylparaben in local dental anesthetic solutions commercially available in Brazil. Furthermore, the drug package inserts were analyzed regarding the description of the presence of methylparaben in the solution.

\section{MATERIAL AND METHODS}

Twelve commercial brands of local anesthetic solutions commonly used in dentistry, purchased from the Brazilian market, were analyzed. Figure 1 shows the characteristics of the solutions used in the study. Four local anesthetic brands were disposable in glass cartridges (G) and eight in plastic cartridges $(P)$. Different lots of the commercial brands were bought in three different Brazilian cities (Piracicaba, Campinas and São Paulo).

To quantify methylparaben, a standard stock solution of $100 \mathrm{mg} . \mathrm{L}^{-1}$ of methylparaben (SigmaAldrich, Milwaukee, WI, USA) in deionized water was used. From this solution, standard working solutions of $1,5,10,15,20,25 \mathrm{mg} . \mathrm{L}^{-1}$ were prepared to establish an analytical curve.

HPLC grade acetonitrile (Mallinckrodt, Rio de Janeiro, RJ, Brazil), Milli-Q water (Millipore, Bedford, MA, USA) and acetic acid (Merck, Rio de Janeiro, $\mathrm{RJ}$, Brazil) were used to prepare the mobile phase. Both acetonitrile and water were filtered through a $0.22 \mu \mathrm{m}$ membrane and degasified before use.

Chromatographic separation was performed by using a Waters liquid chromatograph, consisting of a high pressure pump, model 510, Rheodyne injector, model 7125, UV-Vis detector, model 486. The mobile phase used was acetonitrile:water (75:25 - v/v), $\mathrm{pH} 4.5$, acidified with acetic acid, at a flow rate of $1.0 \mathrm{~mL} \cdot \mathrm{min}^{-1}$. A NovaPak (Waters, Milford, MA, USA) C8 column (150 mm x $3.9 \mathrm{~mm}$ i.d., $10 \mu \mathrm{m}$ ) was used. The injection volume was $10 \mu \mathrm{L}$ and detection was achieved at $257 \mathrm{~nm}$. All injections were performed in triplicate.

Data acquisition and analysis were performed by the software ChromPerfect for Windows, version 3.52, and Report Write Plus (Justice Innovations, Mountain View, CA, USA). The limit of quantification (LQ) of the instrument was determined from the analytical curve equation, $Q L=10 \mathrm{~s} / \mathrm{S}$, being " $\mathrm{s}$ " the standard deviation of the regression equation and " $\mathrm{S}$ " the angular coefficient ${ }^{18}$.

\section{RESULTS}

Methylparaben was found in 9 of the 12 brands studied, in concentrations ranging from $0.01 \%$ to $0.16 \%(\mathrm{~m} / \mathrm{v})$, as shown in Figure 1 . All the anesthetic solutions disposable in plastic cartridges presented methylparaben in their composition. One brand disposable in glass cartridges presented the

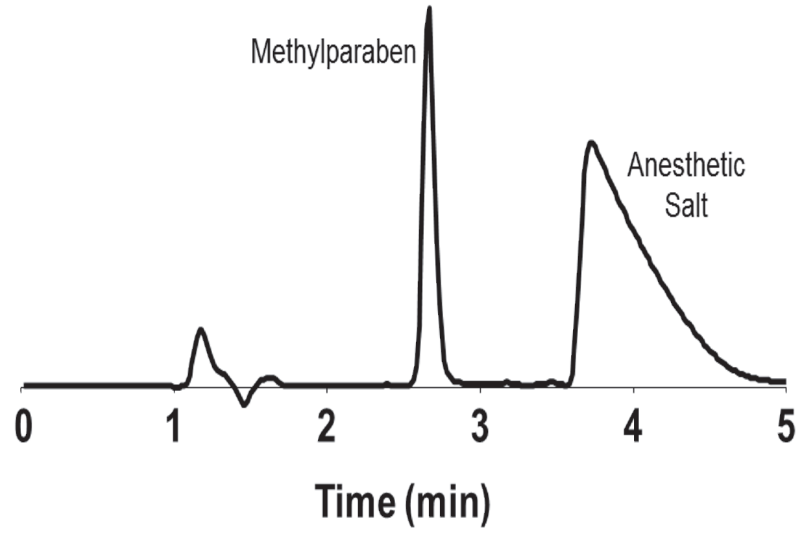

Figure 2- Chromatogram of one sample of local anesthetic for dentistry. Chromatographic conditions: acetonitryle:water $(75: 25-\mathrm{v} / \mathrm{v}), \mathrm{pH} 4.5$, flow rate: $1 \mathrm{~mL}$ . $\mathrm{min}^{-1}$, NovaPaK C8 column, $10 \mu \mathrm{m}$. UV detection at 257 $\mathrm{nm}$

compound. A chromatogram of one of the samples of the local anesthetic is shown in Figure 2.

The presence of methylparaben was mentioned in 9 anesthetic package inserts (Figure 1) and none of them reported its concentration.

\section{DISCUSSION}

Methylparaben is commonly used as preservative in many cosmetic and pharmaceutical products, and also in some food. It has been shown to be an effective antimicrobial agent, and it is used primarily as a bacteriostatic agent to maintain the sterility of some dental anesthetic solutions ${ }^{13}$.

Parabens are allowed as preservatives in foods and the maximum daily ingestion for human has been estimated as 4 to $6 \mathrm{mg} / \mathrm{kg}$. In cosmetics, parabens are allowed in concentrations up to $1 \%{ }^{7}$.

Some studies have reported that methylparaben has rarely been associated with immediate hypersensitivity, even after parenteral exposure. However, Macy, et al.12 (2002) related cases of patients with severe allergic reactions caused by methylparaben, with an approximate incidence of $2 \%$. Those authors also established methylparaben as the unique cause of the immediate hypersensitivity reaction, which was confirmed by cutaneous tests. Kajimoto, et al.10 (1995) related the occurrence of erythematous reactions in patients after the administration of prilocaine containing methylparaben.

According to Soni, et al. ${ }^{21}$ (2005), subcutaneous administration of methylparaben can also cause temporary fatigue, ataxy and respiratory depression at doses higher than $165 \mathrm{mg} / \mathrm{kg}$ in rats. Mason, et al. $^{15}$ (1971) reported that the administration of methylparaben caused mammary adenocarcinoma in rats. In 1988, Routledge, et al. ${ }^{19}$ reported the estrogenic activity of the parabens for the first time 
and suggested that the safety of these substances should be reassessed, particularly in relation to the systemic exposure in humans. Tavares, et al. ${ }^{22}$ (2009) related possible adverse effects of parabens in male fertility. Moreover, at present, some studies have shown the presence of methylparaben in breast tumors, suggesting the possibility of methylparaben having carcinogenic potential ${ }^{5}$.

The use of methylparaben in dental anesthetic cartridges was prohibited in the United States in $1984^{13}$. However, in Brazil this substance is still widely used in dental anesthetic cartridges. There is no data regarding the quantity of methylparaben in the solutions marketed in Brazil until now. Furthermore, manufacturers do not mention the concentration of this component in the drug insert package of their products. All anesthetic solutions contained in plastic cartridges evaluated in the present study showed methylparaben concentrations above the quantification limit (the lowest concentration that can be identified and quantitatively measured with specified accuracy and precision) of the proposed HPLC method. The main alleged reason for using methylparaben in the solutions contained in plastic cartridges is related to the chemical conservation and sterility of the anesthetic solution. The permeability of the plastic could result in oxygen infiltration inside the cartridge, demanding high quantities of preservatives. Another consequence of the plastic permeability is the mandatory use of some kind of bacteriostatic agent, such as methylparaben ${ }^{16}$.

The use of the glass cartridges is justified by the glass characteristics, since it is more hygienic, inert and impermeable. The hygiene of the glass containers is due its manufacturing from natural elements, which protect the products for a longer time and dispense the use of additional preservatives. In addition, it meets all the requirements demanded for storing liquids and foods for human consumption. Glass containers do not react with the product either, resulting in the preservation of taste, odor, color and quality. The absence of pores works as a barrier against any external agent, preserving and increasing the product useful life ${ }^{10,20}$.

Besides the necessary addition of methylparaben, the mechanical aspect of plastic cartridges must be also considered. The rubber-plunger slide is smoother in glass than in plastic cartridges and a higher friction between the plunger and the cartridge walls could interfere with the anesthetic injection. The force used on the syringe plunger is more variable when plastic cartridges are used, and the variable anesthetic flow can cause discomfort to the patient. In addition, the blood reflux during aspiration can be better observed through the transparent walls of the glass cartridges ${ }^{16}$.
In addition, dental anesthetics containers must be disposable and used only once, differing from the multiple-dose flasks used in medicine. Thus, the addition of methylparaben is unnecessary in dental anesthetic cartridges ${ }^{14}$.

The results of the present study showed that the use of methylparaben in dental anesthetic solutions in Brazil must be re-evaluated considering either standardizing or abolishing it from these solutions. Furthermore, one solution contained in a glass cartridge presented the highest concentration of methylparaben among all the solutions evaluated. This fact is inexplicable considering the characteristics of the glass cartridge.

The quantities of methylparaben in the local anesthetic solutions evaluated in the present study largely varied among the manufacturers, since the use of this preservative is not controlled. Therefore, a regulatory legislation regarding this subject is clearly necessary. Despite the methylparaben concentrations observed in the present study were fairly below its lethal dose, this substance is one of the main causes of allergic reactions related to local anesthetics ${ }^{21}$.

There was a clear lack of standardization and information about methylparaben concentration on the drug insert package of the anesthetic solutions evaluated in the present study. This observation is in agreement with the results of a previous study ${ }^{1}$, which referred to the lack of information regarding methylparaben concentration in the drug insert package of other Brazilian drugs.

The present study showed that, except for prilocaine, the commercial brands using glass cartridges did not present methylparaben and are thus feasible alternatives to prevent allergic reactions to methylparaben in susceptible patients.

Agreeing with some authors ${ }^{11}$, the present study shows that further studies are needed to investigate the potential for reducing the concentration of preservatives in products such as local anesthetics.

\section{CONCLUSIONS}

The following conclusions can be stated: 1. Methylparaben concentration varied among solutions from different manufacturers, and it was not indicated in the drug package inserts; 2 . Since the presence of methylparaben in dental anesthetics is not regulated by the Brazilian National Health Surveillance Agency (ANVISA) and this substance could cause allergic reactions, it is important to alert dentists about its possible presence.

\section{ACKNOWLEDGEMENTS}

The authors thank the Fundação de Amparo à Pesquisa do Estado de São Paulo (FAPESP, São 
Paulo, Brazil) for financial support and to the Laboratório de Pesquisas em Cromatografia Líquida (LABCROM, Campinas, SP, Brazil) for providing the facilities involving HPLC measurements. The authors also thank Prof. Carol H. Collins for language assistance.

\section{REFERENCES}

1- Balbani AP, Stelzer LB, Montovani JC. Pharmaceutical excipients and the information on drug labels. Rev Bras Otorrinolaringol. 2006;72:400-6

2- Campbell JR, Maestrello CL, Campbell RL. Allergic response to metabisulfite in lidocaine anesthetic solution. Anesth Prog. 2001;8:21-6.

3- Cartwright PD, Fyhr P. The manufacture and storage of local anesthetics. Reg Anesth. 1988;13:1-12.

4- Cashman AL, Warshaw EM. Parabens: a review of epidemiology, structure, allergenicity, and hormonal properties. Dermatitis. 2005; 16:57-66

5- Darbre PD, Aljarrah A, Miller WR, Coldham NG, Sauer MJ, Pope GS. Concentrations of parabens in human breast tumours. J Appl Toxicol. 2004;24:5-13.

6- Eggleston ST, Lush LW. Understanding allergic reactions to local anesthetics. Ann Pharmacother. 1996;30:851-7.

7- Elder RL. Final report on the safety assessment of methylparaben, ethylparaben, propylparaben and butylparaben. J Am Coll Toxicol. 1984;3:147-209.

8- Hondrum SO, Ezell $\mathrm{JH}$. The relationship between $\mathrm{pH}$ and concentrations of antioxidants and vasoconstrictors in local anesthetic solutions. Anesth Prog. 1996;43:85-91.

9- Hondrum SO, Seng GF, Rebert NW. Stability of local anesthetics in the dental cartridge. Anesth Pain Control Dent. 1993;2:198-202 10- Kajimoto Y, Rosenberg ME, Kyttä J, Randell T, Tuominen M, Reunala $T$, et al. Anaphylactoid skin reactions after intravenous regional anaesthesia using $0.5 \%$ prilocaine with or without preservative - a double-blind study. Acta Anaesthesiol Scand. 1995;39:782-4.
11- Lundov MD, Moesby L, Zachariae C, Johansen JD. Contamination versus preservation of cosmetics: a review on legislation, usage, infections, and contact allergy. Contact Dermatitis. 2009;60:70-8.

12- Macy E, Schatz M, Zeiger RS. Immediate hypersensitivity to methylparaben causing false-positive results of local anesthetic skin testing or provocative dose testing. The Permanente Journal. 2002;6:4.

13- Malamed SF. Allergy and toxic reactions to local anesthetics. Dent Today. 2003;22:114-6,118-21.

14- Malamed SF. Handbook of local anesthesia. $4^{\text {th }}$ ed. St. Louis: Mosby; 1997.

15- Mason MM, Cate CC, Baker J. Toxicology and carcinogenesis of various chemicals used in the preparations of vaccines. Clin Toxicol. 1971;185-204.

16- Ramacciato JC, Meechan JG. Recent advances in local anaesthesia. Dent Update. 2005;32:8-10,12-4.

17- Renton T. Prevention of iatrogenic inferior alveolar nerve injuries in relation to dental procedures. Dent Update. $2010 \mathrm{Jul}-$ Aug;37(6):350-2, 354-6, 358-6.

18- Ribani $\mathrm{M}$, Collins $\mathrm{CH}$, Bottoli CB. Validation of chromatographic methods: evaluation of detection and quantification limits in the determination of impurities in omeprazole. J Chromatogr A. 2007; 13:201-5.

19- Routledge EJ, Parker J, Odum J, Ashby J, Sumpter JP. Some alkyl hydroxy benzoate preservative (parabens) are estrogenic. Toxicol Appl Pharmacol. 1998;153:12-9.

20- Shojaei AR, Haas DA. Local anesthetic cartridges and latex allergy: a literature review. J Can Dent Assoc. 2002;68:622-6.

21- Soni MG, Carabin IG, Burdock GA. Safety assessment of esters of p-hydroxybenzoic acid (parabens). Food Chem Toxicol. 2005;43:985-1015.

22- Tavares RS, Martins FC, Oliveira PJ, Ramalho-Santos J, Peixoto FP. Parabens in male infertility - is there a mitochondrial connection? Reprod Toxicol. 2009;27:1-7. 


\section{ERRATUM}

Due to a publishing error the article "Methylparaben concentration in commercial Brazilian local anesthesics solutions", published at Journal of Applied Oral Science 20(4):444-8 was printed with the following errors:

\section{Page 445}

Figure 1 - Concentration of methylparaben in different cartridges available on the Brazilian market

Line 1, column 6 should be read "CV (\%)"

Line 7 , column 7 should be read "Yes" 